\title{
PENGEMBANGAN PERANGKAT PEMBELAJARAN BERBASIS INKUIRI TERBIMBING UNTUK MELATIH LITERASI SAINS SISWA
}

\author{
Sri Sumarti' ${ }^{1)}$, Yuni Sri Rahayu' ${ }^{2)}$, Madlazim ${ }^{3)}$ \\ ${ }^{1)}$ Mahasiswa Program Studi Pendidikan Sains, Program Pascasarjana Universitas Negeri Surabaya \\ ${ }^{2), 3)}$ Dosen Pascasarjana Prodi Pendidikan Sains Univesrtitas Negeri Surabaya \\ E-mail: rati,sumrati@gmail.com
}

\begin{abstract}
This research aims to develop guided inquiry based teaching materials which is valid, practical, and effective to facilitate the students' scientific literacy. The development of teaching material used the 4D model and was tested in grade 7th-D of SMP GEMA 45 in the second semester of 2014/2015 by using the Pre-Experimental One-Group Pretest-Posttest Design. The data collection used documentation observation, test, and quetionnaires. The data analysis techniques used quantitative descriptive analysis. The results of this research are:1) Teaching material developed is valid categorised to be use consisted of Syllabus, Lesson Plan, Student Worksheet, Student Book and Test of student learning outcomes; 2) The practicality of teaching material in terms of a good category in feasibility of lesson plans, the students' activities in accordance with inquiry model and students give a positive responses toward teaching material and implementation of teaching material developed; and 3) The teaching material effectiveness in terms of: (a) Improving students' learning achievement seen from the individual and classical completeness; (b) Improving students' scientific literacy by getting gain score between middle until high category. Based on data analyzed the teaching materials based on guided inquiry are valid, practical, and effective to facilitate the students' scientific literacy.
\end{abstract}

Keywords: Teaching Material, Guided Inquiry, Scientific Literacy

\begin{abstract}
Abstrak: Penelitian ini bertujuan untuk menghasilkan perangkat pembelajaran berbasis inkuiri terbimbing yang layak (valid, praktis, dan efektif) untuk melatih literasi sains siswa. Pengembangan perangkat pembelajaran menggunakan model 4D dan diujicobakan di kelas VII-D SMP GEMA 45 semester genap tahun ajaran 2014/2015 dengan One-Group Pretest-Posttest Design. Pengumpulan data menggunakan metode dokumentasi, observasi, tes, dan angket. Teknik analisis data menggunakan analisis deskriptif kuantitatif. Hasil penelitian ini menunjukkan,: 1) Perangkat pembelajaran yang dikembangkan berkategori valid; 2) Perangkat pembelajaran berketagori praktis ditinjau dari keterlaksanaan RPP, aktivitas siswa sesuai dengan tahap-tahap model inkuiri, dan siswa merespon positif perangkat yang dikembangkan dan implementasinya; serta 3) Perangkat pembelajaran telah efektif ditinjau dari: (a) Peningkatan pengetahuan siswa (b) Peningkatan literasi sains siswa. Berdasarkan hasil analisis data dapat disimpulkan bahwa perangkat pembelajaran berbasis inkuiri terbimbing yang dikembangkan valid, praktis, dan efektif untuk melatih literasi sains siswa sehingga layak untuk digunakan.
\end{abstract}

Kata kunci: Perangkat Pembelajaran, Inkuiri Terbimbing, Literasi Sains

\section{PENDAhuluan}

Literasi sains (scientific literacy) menjadi keharusan bagi setiap orang. Literasi sains menjadi sangat penting bagi seseorang karena maju mundurnya suatu bangsa salah satunya ditentukan oleh kualitas daya manusia yang memiliki literasi terhadap sains dan teknologi (UNESCO, 2008).

Penelitian tentang kemampuan literasi sains siswa dalam skala internasional diselenggarakan oleh Organization for Economic Co-operation and Development (OECD) melalui Programme for International Student Assesment (PISA). Berdasarkan hasil penilaian PISA dan TIMSS (Trends In International Mathematics and Science Study) menunjukkan bahwa literasi siswa Indonesia masih rendah dan cenderung menurun dari tahun ke tahun.

Literasi sains siswa yang rendah dapat dijadikan salah satu gambaran bahwa pembelajaran sains di Indonesia masih membutuhkan perbaikan. Fakta di lapangan menunjukkan bahwa siswa sangat pandai menghafal, tetapi kurang terampil dalam mengaplikasikan pengetahuan yang dimilikinya dalam pemecahan masalah

Berdasarkan hasil uji coba terbatas di SMP Bahrul Ulum Surabaya literasi sains siswa masih perlu adanya perbaikan terutama pada aspek mengidentififasi isu ilmiah dan menggunakan bukti ilmiah. Kedua aspek ini tidak hanya menitik beratkan pada pengetahuan saja akan tetapi juga kepada keterampilan proses sainn.

Kurikulum 2013 berusaha untuk menjembatani 
agar literasi sains siswa berkembang. Pembelajaran Kurikulum 2013 tidak hanya menekankan pada pengetahuan konseptual saja tetepi juga keterampilan proses sains yang tercantum pada KD ke 4 .

Perangkat pembelajaran dapat dijadikan alat untuk melatih literasi sains siswa apabila perangkat pembelajaran tersebut memungkinkan siswa untuk menemukan sendiri pengetahuan mereka.

Hasil penelitian Eijck and Roth (2009) menunjukkan bahwa pengalaman-pengalaman autentik tentang sains (authentic science experiences) dapat dijadikan jalan untuk meningkatkan literasi sains siswa. Salah satu model pembelajaran yang memberikan kesempatan pada siswa untuk aktif mengembangkan pemahaman konsep dengan mengombinasikan pengetahuan mereka dengan keterampilan bernalar dan berpikirnya yakni pembelajaran inkuiri. Pembelajaran inkuiri juga sejalan dengan pendekatan ilmiah (scientific approach) yang merupakan essensi dari Kurikulum 2013.

Literasi sains tidak hanya terkait dengan pemahaman terhadap fakta-fakta, tetapi juga memahami hakikat sains (the nature of science) dan memiliki kemampuan inkuiri sains. Hasil penelitian Fittel (2010) investigasi sains melalui inkuiri meningkatkan pemahaman terhadap literasi sains dan hakikat sains. Hal ini juga sejalan dengan penelitian oleh McCright (2012), hasil penelitiannya menunjukkan bahwa latihan inkuiri dapat meningkatkan pemahaman sains dan mengasah keterampilan penelitian sains pada materi perubahan iklim.

Menurut teori perkembangan kognitif Piaget, anak yang berusia 11 tahun sampai dewasa telah mencapai perkembangan operasional formal. Siswa seharusnya sudah dapat berpikir abstrak dan menalar sehingga sudah dapat membuat hipotesis, mampu memecahkan masalah, dan menemukan suatu konsep melalui bimbingan guru. Siswa butuh bimbingan dan perantara untuk berpikir abstrak dan menalar. Siswa dapat berkonsentrasi pada pembangunan pengetahuan baru dan belajar tentang strategi yang berguna dalam setiap tahap proses inkuiri dengan adanya bimbingan (Khulthau, 2012). Dengan demikian inkuiri terbimbing dianggap sesuai untuk diterapkan pada siswa SMP.

Penilaian litersi sains PISA menekankan pada masalah kehidupan nyata (OECD, 2013a). Materi pemansan global dianggap penting dalam literasi sains dikarenakan materi ini merupakan fenomena alam yang sedang kita hadapi saat ini. Kemampuan literasi sains siswa yang baik dapat digunakan sebagai dasar untuk mengurangi pemanasan global.

Berdasarkan hasil penilaian PISA terhadap literasi sains siswa dan berdasarkan tuntutan kurikulum 2013 maka peneliti bermaksud mengadakan penelitian pengembangan perangkat perangkat pembelajaran berbasis inkuiri terbimbing untuk menfasilitasi literasi sains siswa pada materi pemanasan global

\section{METODE PENELITIAN}

Penelitian ini merupakan jenis penelitian pengembangan, yaitu pengembangan perangkat pembelajaran berbasis inkuiri terbimbing untuk menfasilitasi literasi sains siswa. Pengembangan yang akan dilakukan mengacu pada model pengembangan 4D (four $D$ models). Ujicoba perangkat pembelajaran pada materi pemanasan global menggunakan desain penelitian one-group pretest-postest design. Perangkat pembelajaran yang disusun berupa silabus, rencana pelaksanaan pembelajaran (RPP), LKS (Lembar Kegiatan Siswa), tes hasil belajar dan tes literasi sains. Perangkat pembelajaran tersebut selanjutnya divalidasi oleh pakar sebelum diimplemetasikan di kelas. Subjek dalam penelitian ini adalah 32 siswa kelas VII-D SMP GEMA 45 Surabaya

Instrumen yang digunakan dalam pengumpulan data terdiri dari lembar validasi perangkat pembelajaran, lembar pengamatan keterlaksanaan RPP, lembar pengamatan aktivitas siswa, angket respon siswa, tes hasil belajar, dan tes literasi sains.

Data hasil validasi perangkat pembelajaran, pengamatan keterlaksanaan RPP, aktivitas siswa, respon siswa, tes hasil belajar, dan tes literasi sains siswa dianalisis secara kuantitatif. Besarnya peningkatan penguasaan konsep dan keterampilan berpikir kritis dianalisis dengan n-gain (gain ternormalisasi) (Hake, 2009).

\section{HASIL PENELITIAN DAN DISKUSI}

\section{A. Validitas Perangkat Pembelajaran}

Validasi perangkat pembelajaran yang meliputi silabus, RPP, LKS, tes hasil belajar dan tes literasi sains siswa secara keseluruhan mendapat kategori sangat baik. Dengan demikian perangkat pembelajaran yang dikembangkan layak digunakan dalam pembelajaran.

\section{B. Keterlaksanaan RPP}

Pengamatan terhadap keterlaksanaan RPP dalam pembelajaran dilakukan oleh dua pengamat. Pengamatan dilakukan pada dua kali pertemuan, pertemuan I tentang efek gas rumah kaca dan pertemuan II mempelajari dampak pemanasan global dan solusinya. Rata-rata penilaian pegamat pada pertemuan I sebesar 3,32 dengan persentase kesesuaian antar pengamat sebesar $97,48 \%$. Rata-rata penilaian kedua pengamata pada pertemuan II sebesar 3,53 dengan persentase kesesuaian antar pengamat sebesar 91,60\%. Terlaksananya seluruh kegiatan juga diiringi dengan pengelolaan waktu dan suasana kelas yang terkondisi dengan baik. 


\section{Aktivitas Siswa}

Pencatatan aktivitas siswa pada saat KBM akan memberikan gambaran kegiatan-kegiatan siswa pada saat pembelaharan dengan inkuiri terbimbing. Kegiatan siswa selama KBM akan mempengaruhi kesempatan siswa dalam belajar. Broophy dan Good (dalam Muijs \& David, 2008) mengemukakan bahwa faktor penting yang mempengaruhi kesempatan untuk belajar adalah time on taks, yaitu banyaknya waktu yang dihabiskan

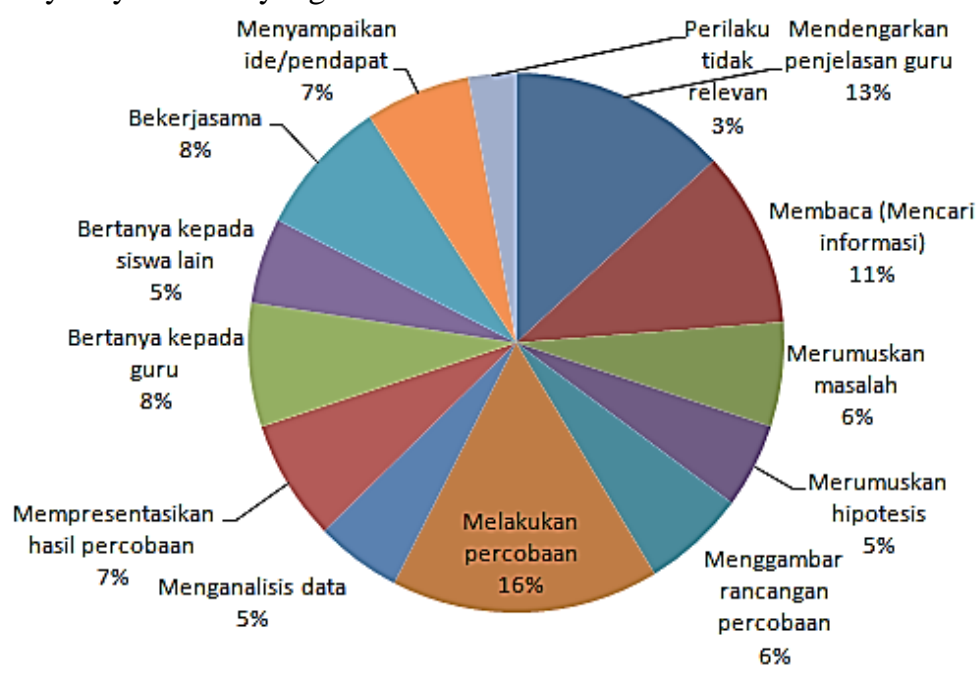

Gambar 1. Diagram Rata-rata Aktivitas siswa siswa untuk terlibat KBM dan bukan dengan kegiatankegiatan lain seperti berjalan-jalan di dalam kelas.

Aktivitas siswa yang paling banyak dilakukan siswa selama pembelajaran dengan berbasis inkuiri terbimbing adalah melakukan percobaan Paling sedikit siswa melakukan aktivitas yang tidak relevan dengan persentase $3 \%$.). Rata-rata aktivitas siswa pada tiap pertemuan seperti ditunjukkan Gambar 1 berikut ini.
Aktivitas siswa yang tinggi selama pembelajaran menunjukkan bahwa pembelajaran berpusat pada siswa. Siswa mampu menemukan konsepnya sendiri seperti dalam teori pembelajaran bermakna Ausubel yang menekankan pentingnya siswa mengasosiasi pengalaman, fenomena, dan fakta-fakta baru ke dalam sistem pengertian yang telah siswa. Pengajaran yang berpusat pada siswa memungkinkan konsep-konsep yang penting dalam pembelajaran dapat tersimpan lama dalam benak siswa. Hal ini sesuai dengan teori pemrosesan informasi bahwa keterlibatan siswa secara aktif dalam pembelajaran menyebabkan penyimpanan informasi ke memori jangka panjang (Slavin, 2009)

\section{Respon Siswa}

Respon siswa meliputi ketertarikan penggunaan perangkat, kebaruan perangkat, kemudahan perangkat, kelanjutan pengunaan perangkat, peran guru dalam mengajar serta kemudahan soal tes. Siswa memberikan respon yang postitif komponen-komponen tersebut.

Respon keberminatan siswa menggunakan perangkat pembelajaran berbasis inkuiri pada materi selanjutnya mendapatkan skor $78,13 \%$. Hal ini berarti siswa mendukung, merasa senang, dan berminat terhadap pembelajaran dengan menggunakan perangkat hasil pengembangan berbasis inkuiri terbimbing untuk melatihkan literasi sains. Siswa sangat antusias saat mengerjakan LKS hal ini dibuktikan dengan 97\% aktivitas siswa terkait dengan pembelajaran yang berbasis inkuiri terbimbing. Menurut Maher dan Zuhro
(2009) beberapa siswa memiliki learning goal orientation, siswa ini termotivasi secara internal seperti kepuasan untuk belajar sesuatu yang baru (Arrends, 2012). Siswa merasa berminat pada pembelajaran inkuiri terbimbing karena pembelajaran inkuiri masih terasa baru.

\section{E. Hasil Belajar}

Hasil belajar siswa yang dicapai siswa setelah mengikuti proses pembelajaran meliputi sikap dan pengetahuan. Sikap yang diamati dalam proses pembelajaran terdiri dri sikap spiritual dan sosial. Sikap spriritual yaitu diukur yaitu rasa syukur, dan sikap sosial yang diukur yaitu kejujuran dan ketelitian. Ketuntasan hasil belajar sikap disajikan pada Gambar 2 di bawah ini.

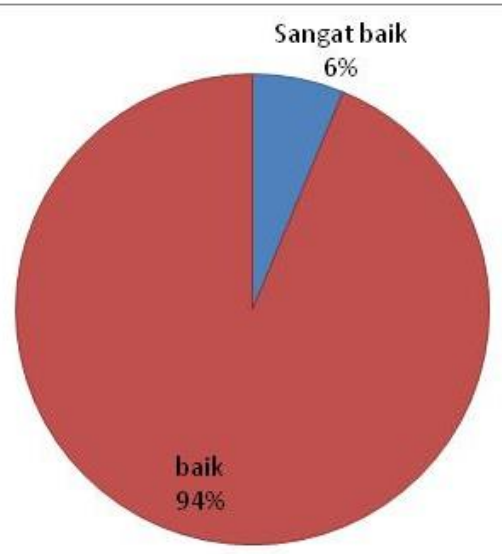

Gambar 2. Diagram Hasil Belajar Sikap 
Berdasarkan Gambar 2 sebanyak $96 \%$ siswa memiliki sikap spiritual dan sosial yang baik dan $6 \%$ siswa memiliki sikap yang sangat baik. Hal ini menunjukkan bahwa sikap siswa selama dua kali pertemuan memiliki kategori Baik (Permendikbud No 81A Tahun 2013). Sikap jujur dan teliti dapat dientegrasikan pada saat melakukan percobaan (Zuriah, 2008). Dalam pembelajaran berbasis inkuiri siswa akan terbiasa berperilaku sebagai saintis (objektif, jujur kretaif dan menghargai orang lain) (Rustaman, 2005). Jadi perangkat pembelajaran inkuiri terbimbing dapat mengembangkan rasa syukur, jujur dan teliti.

Tes pengetahuan siswa diberikan sebelum dan sesudah dilaksanakan proses Kegiatan Belajar Mengajar (KBM). Pemberian tes sebelum melaksanakan KBM bertujuan untuk melihat kemampuan awal siswa dan pemberian tes setelah melaksanakan KBM untuk melihat kemampuan siswa setelah diajarkan dengan model pembelajaran berbasis inkuiri terbimbing

Berdasarkan tes hasil belajar siswa diperoleh hasil posttest yang meningkat dengan skor peningkatan mulai kategori sedang $(0,5)$ sampai tinggi $(1,0)$. Peningkatan nilai pretest dan posttest disajikan melalui kategori $N$ gain score dalam Gambar 3 berikut.

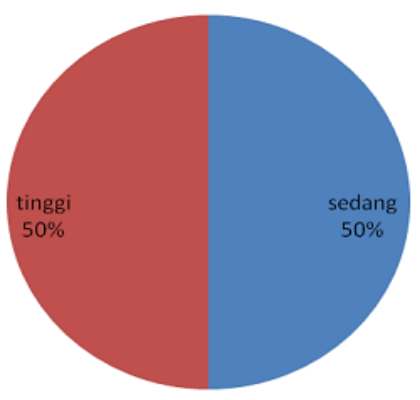

Gambar 3. Kategori $N$-gain score

Pada saat pretest tidak ada siswa yang tuntas sehingga secara klasikal siswa tidak tuntas, sedangkan setelah dijarkan dengan perankat pembelajaran inkuiri terbimbing 93,75\% siswa tuntas dan tuntas secara klasikal. Pemahaman terhadap konsep sains yang merupakan domain terpenting dari perkembangan literasi sains siswa (Trowbridge \& Bybee 1996). Hal ini sesuai dengan hasil uji coba terbatas, siswa yang memiliki pengetahuan yang baik, juga memiliki literasi sains yang baik.

Peningkatan hasil belajar pengetahuan siswa setelah penerapan pembelajaran berbasis inkuiri terbimbing menunjukkan bahwa tahap-tahap dalam pembelajaran tersebut mampu membantu siswa mengkonstruksi konsep sehingga dapat meningkatkan daya akomodasi konsepnya. Tingginya nilai peningkatan hasil belajar dan ketuntasan individual maupun klasikal ini didukung oleh aktivitas siswa dan respon siswa yang sangat baik terhadap pembelajaran berbasis inkuiri terbimbing.
Pembelajaran inkuiri dapat mengembangkan pemahaman siswa terhadap konsep sains. Menurut NRC (2000) ikuiri juga mengacu pada kegiatan mengembangkan pengetahuan dan pemahaman ide ilmiah, seperti bagaimana ahli sains mempelajari alam. Hasil diperkuat dengan hasil penelitian Maliyah (2012), Astuti (2013), dan David (2006) yang menyatakan bahwa pembelajaran dengan menggunakan proses pembelajaran inkuiri terbimbing dapat meningkatkan kognitif siswa.

\section{F. Literasi Sains Siswa}

Penialian literasi sains siswa didasarkan pada kompetensi ilmiah yang meliputi mengidentifikasi isu ilmiah, menjelaskan fenomena secara ilmiah dan menggunakan bukti ilmiah (OECD, 2013). Kemampuan iterasi sains siswa sebelum pembelajaran dilihat dari nilai pretest literasi sains. Setelah proses pembelajaran dengan menggunakan perangkat pembelajaran yang berbasis inkuiri terbimbing, siswa diberikan posttest. Pada saat pretest belum ada siswa yang tuntas sehingga ketuntasan klasikal belum tercapai. Pada saat posttest $75 \%$ tuntas, maka secara klasikal sudah tuntas. Skor peningkatan (gain-score) yang diperoleh setiap siswa berkisar antara 0,33 (sedang) - 0,77 (tinggi). Peningkatan nilai pretest dan posttest disajikan melalui kategori $\mathrm{N}$-gain score dalam Gambar 4 berikut.

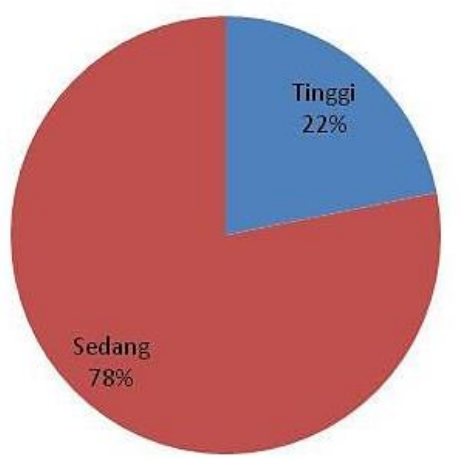

Gambar 4 Kategori N-gain score Literasi Sains Siswa

Peningkatan kemampuan literasi sains dapat dilihat dari n-gain dari 32 siswa (Tabel 4.18) berkisar antara 0,33 (sedang) -0,77 (tinggi). Peningkatan yang ditunjukkan oleh hasil analisis dengan menggunakan ngain ini menunjukkan tentang penerapan dari pengembangan perangkat pembelajaran berbasis inkuiri terbimbing dalam meningkatkan literasi sains siswa pada materi pemanasan global. Hal ini sesuai dengan Fittel (2010) investigasi sains melalui inkuiri meningkatkan pemahaman terhadap literasi sains dan hakikat sains. Penelitian Carlson (2008) juga menunjukkan bahwa pembelajaran inkuiri terbimbing berpotensi untuk meningkatkan literasi sains siswa 
dilihat dari pemahaman siswa terhadap konsep dan inkuiri sains pada materi ekologi.

PISA mendeskripsikan enam tingkat/ level kemampuan literasi sains yang berkaitan dengan kompetensi ilmiah setiap levelnya. Hasil belajar literasi sains siswa pada tiap level sebelum dan sesudah pembelajaran dapat dilihat pada Gambar 5 berikut ini.

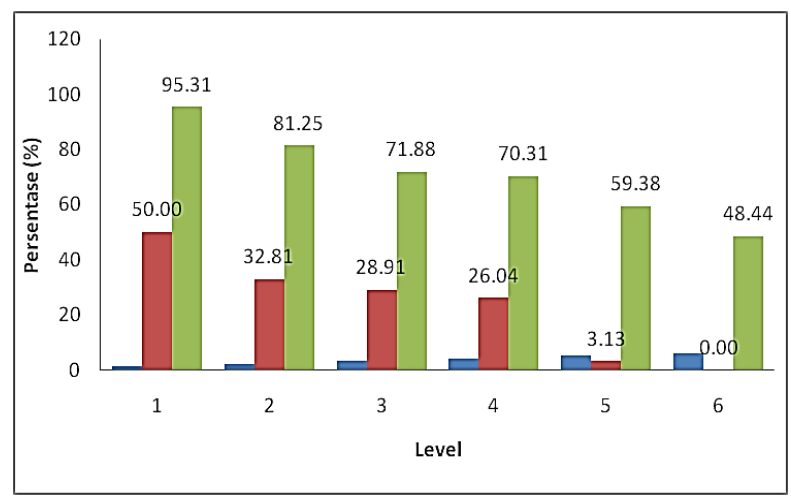

Gambar 5. Grafik Hasil Belajar Literasi Sains Siswa pada Tiap Level

Kemampuan literasi sains pada keenam level meningkat setelah diterapkan perangkat pembelajaran berbasis inkuiri. Persentase siswa yang menjawab benar menurun disetiap levelnya. Hal ini dikarenakan semakin tinggi levelnya maka semakin kompleks bentuk soal. Soal dengan level 6 menggabungkan dua kompetensi yang meliputi mengidentifikasi isu ilmiah dan menjelaskan fenomena ilmiah. Sebagaian besar siswa $81,25 \%$ telah mampu menjawab dengan benar soal dengan level 2 (Gambar 4) setelah diterapkan pembelajaran inkuiri terbimbing. Pada Level 2 siswa telah mengusai kemampuan dasar literasi sains, pada level ini siswa mulai dapat mendemonstrasikan kompetensi ilmiah (OECD, 2013).

Keenam level literasi sains terkemas dalam ketiga kompetensi litersi sains yang meliputi: mengidentifikasi isu ilmiah, menjelaskan fenomena secara ilmiah dan menggunakan bukti ilmiah. Kemampuan siswa pada setiap kompotensi literasi sains ditunjukkan Gambar 6 berikut ini.

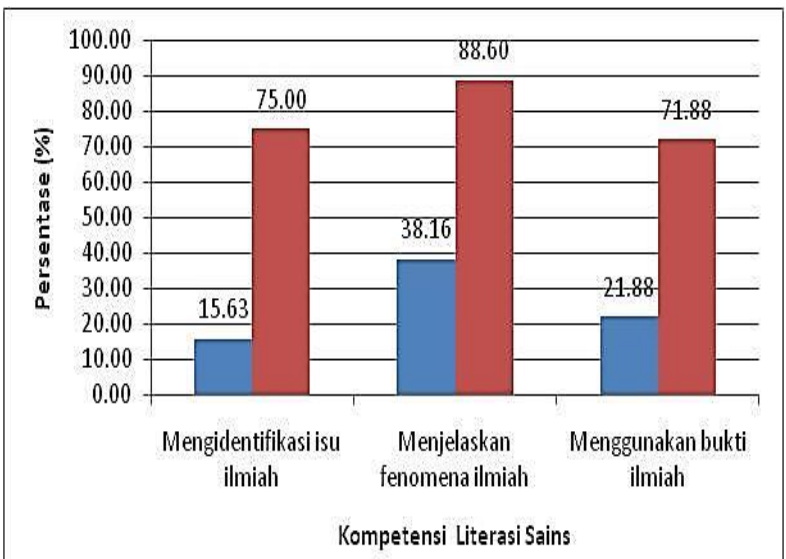

Gambar 6. Grafik Hasil Belajar Literasi Sains Siswa Tiap Kompetensi Literasi Sains
Berdasarkan Gambar 6 ketiga kompetensi ilmiah literasi sains meningkat setelah diterapkan pembelajaran berbasis inkuiri terbimbing. Kompetensi menjelaskan fenomena ilmiah memperoleh persentase jawaban benar yang paling besar dibandingkan dengan kompetensi literasi sains yang lain baik pada pretest dan posttest (Gambar 6).

Hal ini dikarenakan kompetensi ini menitik beratkan pada aspek pengetahuan. Siswa telah terbiasa mengerjakan soal yang menekankan aspek pengetahuan. Kompetensi yang memiliki persentase jawaban benar paling kecil pada saat pretest dan posttest yaitu kompensi menggunakan bukti ilmiah. Hal sesuai dengan hasil penilaian dari PISA 2006 menunjukkan bahwa siswa Indonesia memiliki memiliki kemampuan paling rendah dalam menggunakan bukti ilmiah, dan kemampuan yang baik dalam menjelaskan fenomena ilmiah (OECD, 2006).

Ketiga kompetensi ini dipilih karena memerlukan kemampuan kognitif siswa seperti berfikir induktif dan deduktif, berfikir kritis, kritis dalam membuat keputusan, transformasi informasi dan berfikir dalam menggunakan sains (Thomson et al, 2013). Aktivitas inkuiri terbimbing dapat mengembangkan pemahaman, mendorong berfikir kritis dan analitis (Hanson, 2006). Kemampuan berfikir kritis dan analitis menjadi dasar untuk menjawab kompetensi literasi sains, sehingga pembelajaran inkuiri tembimbing dapat meningkatkan kompetensi ilmiah siswa. Hal ini dibuktikan degan meningkatnya literasi sains siswa pada ketiga kompetensi setelah penerapan pembelajaran dengan inkuiri terbimbing.

\section{KESIMPULAN}

Berdasarkan hasil analisis, diskusi, dan pembahasan, maka dapat dibuat kesimpulan bahwa perangkat pembelajaran berbasis inkuiri terbimbing yang dikembangkan sudah valid, praktis, dan efektif untuk melatihkan literasi sains sehingga layak digunakan.

\section{REFERENSI}

Alberta Learning. (2004). Focus on Inquiry: A Teacher's Guide to implementing Inquiry-based LearniPng. Edmonton, AB: Alberta Education.

American Association for the Advancement of Science. (1990). Science for All Americans. Oxford: Oxford Univercity Press.

Arrends, Richard I. (2012). Learning to Teach Ninth Edition. New York: McGraw-Hill.

Barthlow, Michelle J. (2011). The Effectiveness of Process Oriented Guided Inquiry Learning to Reduce Alternate Conceptions in Secondary Chemistry (Unpublished Doctoral dissertation).Liberty University 
Borich, Garry. D. (1994). Observation Skill for Effective Teaching. Nw York: Mac Millan Publishing Company.

Buckley, B., Hopkins, E. J. and Whitaker, R. (2004). Weather. Sydney, Australia: Pan Macmillan Australia.

Bungin, Burhan. (2007). Penelitian Kualitatif Kominikasi, Ekonomi, Kebijakan Publik, dan Ilmu Sosial Lainnya. Jakarta: Kencana Prenada Media Group.

Carlson, Jennifer Lynn. (2008). Effect of Theme-based, Guided Inquiry Instruction on Science Literacy in Ecology. (Thesis Master of Science in Appied Science Education). Michigan Technology University.

Creswell, John W. (2008). Educational Research: Planning, Conducting, and Evaluating Quantitative and Qualitative Research. New Jersey: Pearson.

Casper, Julie Kerr. (2009). Changing Ecosystems: Effect of Global Warming. New York : Fact on File.

Depdiknas. (2004). Pengembangan Bahan Ajar. Jakarta: Depdiknas.

Depdiknas. (2006). Pedoman Mimilih dan Menyusun Bahan Ajar. Jakarta: Depdiknas.

Depdiknas. (2008). Pedoman Umum Pengembangan Bahan Ajar Sekolah Menengah Atas. Jakarta: Depdiknas.

Dutch, Steven I. (2010). Enclycopedia of Global Warming Volume I: Abrupt Climate ChangeEnergy Policy Act 1992. New Jersey: Salem Press.

Eijck, Micheil van and Roth, Wolf-Michael. (2009). "Authentic Science Experiences as A Vehicle to Change Students' Orientations Toward Science and Scientific Career choices: Learrning From The Paths Follewed by Brad". Cultural Studies of Science Education. Vol. 4, pp. 611-638.

Fittel, David. (2010). Inquiry-Based Science in A Primary Classroom: Proffesional Development Impacting Practice. (Thesis Master of Education), Queensland University of Technology.

Gorrmally, Cara., Bricman, Peggy., and Lutz, Marry. (2012). “ Developing a Test of Sceintific Literacy Skill (TSOSL): Measuring Undergraduates's Evaluation of Scientific Information and Arguments". CBE-Life Sciences Education. Vol. 11, pp. 364-377

Gulo. 2008. Strategi Belajar Mengajar. Jakarta: PT. Grasindo

Heppner, F. H., Kouttab, K. R., and Croasdale, W. (2006). Inquiry: Does it Favor the Prepared
Mind? American Biology Teacher, Vol. 68 No 7, pp. 390-392.

Hake, R. (1998). "Interactive-Engagement Versus Traditional Methods: A six-thousand-Student survey of Mechanics Test data for Introductory Physic Courses". Journal American association of Physic Teacher. Volume 66, No 1, pp. 64-74.

Hanson, David M. (2006). Instructor's Guide to Process-Oriented Guided-Inquiry Learning. Lisle : Pasicif Crest.

Ibrahim, Muslimin. (2007). Pembelajaran Inkuiri. Surabaya: UNESA-University Press

Institute of Medicine of the National Academies. (2011). Climate Change, the Indoor Environment . Washington, DC: The National Academies Press.

Joyce, Bruce., Weill, Marsha. and Calhoun, Emily. (2009). Models Of Teaching. New York: Pearson

Kemendikbud. (2013a). Materi Pelatihan Guru Implementasi kurikulum 2013- SMP/MTS-Ilmu Pengetahuan Alam. Jakarta : Depdikbu

Kemendikbud. (2013b). Peraturan menteri pendidikan dan kebudayaan Republik Indonesia tentang Silabus sekolah menengah pertama. Jakarta: Depdikbud

Kessler, Jamess H. and Galvan, Patricia M. (2007). Inquiry in Action-Investigating Matter Through Inquiry Third Edition. American Chemical Society Education Division

Sejati, Kuncoro. (2011). Pemanasan Global, Pangan, dan Air: Masalah, Solusi, dan Perubahan Konstelasi Geopolitika Dunia. Yogyakarta: Gadjah Mada University Press

Kuhlthau, Carol C., Maniotes, Leslie and Capari, ann K. (2007). Guided Inquiry: Learning in The 21st Century. London : Libraries Unlimeted.

Kuhlthau, Carol Coller. (2012). Guided Inquiry: Learning in the 21st Century. London: Rutgers University.

Lestari, Ika. (2013). Pengembangan Bahan Ajar Berbasis Kompetensi. Padang: Akademia Permata

Majid, Abdul. (2008). Perencanaan Pembelajaran Mengembangkan Standar Kompetensi Guru. Bandung: rosda karya.

Maslin, Mark. (2002). Stormy Weather. London : Apple Press

Maslin, Mark. (2004). Global Warming: A Very Short Introduction. New York : Oxford University press.

Maslin, Mark. (2012). "Commentary: Cascading Uncertancy in Climate Change Models and its implication for Policy. The Geoghraphical Journal, pp. 1-8. 
Mcright, Aaron M. (2012). 'Enhancing students' scientific and quantitative literacy through and inquiry-based learning project on climate change.. Journal of the Scholarship of Teaching and Learning. Vol. 12 No 4, pp. 86-102.

Meltzer,D.E. (2002). "The Meaning of Scientific Literacy". Journal of Environment \& Science Education. Volume 4, No 3, pp 275-288

Muijs, Daniel and David Reynold. (2008). Effective Teaching Evidence and Practice. London: Sage Publication Ltd London

National Research Council. (2001). Under The Weather: Climate, Ecosystems, And Infectious Disease. Washington, DC : National Academy Press.

National Research Council. (2006). Inquiry and The National Science Education Standard: A Guide for Teaching and Learning. Washington, DC: National Academy Press.

National Science Education Standard. (1992). Observe Change Learn. Washington, DC: National Academy Press

Neirburger., Edinger., and Bonner. (1995). Memahami Lingkungan Atmosfer Kita. Bandung: ITB

Nieven, Nienke (1999). Prototyping to Reach Product Quality. Springer Science+Business Media Dordrecht

Nur, Muhammad, Wikandari, Prima R, dan Sugiarto, Bambang. (2008). Teori Pembelajaran Kognitif. Surabaya : Pusat Sins dan Matematika Sekolah.

Nur, Muhammad. (2011). Modul KeterampilanKeterampilan Proses Sains.Surabaya: PSMS UNESA

OECD. (2006). Asessesing Scientific, Reading, and Mathematical Literacy: A Framework for PISA 2006. s.l: OECD Publishing

OECD. (2013a). PISA 2012 Assesment and Analitycal Framework Mathematics, Reading, Science, Problem Solving and Financial Literacy. s.l. : OECD Publishing.

OECD. (2013b). PISA 2012 Result: What Students Know and Can Do-Student Perfomance in Mathematics, Reading and Science (Valume I). s.1. : OECD Publishing.

Opara, Jacinta Abragachi and Oguzor, Nkasiobi Silas. (2011). "Inquiry Intructional Methode and the School science curriculum". Current Research of Social sciences, pp. 188-198.

Permendikbud RI Nomor 65. (2013). Standar Proses Pendidikan Dasar dan Menengah. Jakarta.

Permendikbud RI Nomor 81A. (2013). Implementasi Kurikulum. Jakarta

Prastowo, Tjipto.( 2012). Lecture Notes: Earth Science. Surabaya: Buku Pegangan Matakuliah IPBA
Prince, Michail and felder, Richard. (2007). "The Many Faces of Inductive Teaching and Learning". Journal of College Science Teaching Vol 36 No 5, pp. 14-20.

Ratumanan, Tanwaey G. dan Laurens, Theresia. (2011). Penilaian Hasil Belajar. Surabaya: Unesa University Press

Riduwan. (2010). Skala Pengikuran Variabel-Variabel Penelitian. Bandung: Alfa Beta.

Rusbiantoro, Dadang. (2008). Global Warming for Beginner: Pengantar komprehensif tentang pemanasan global. Yogyakarta: $\mathrm{O}_{2}$

Rustaman, Nuryani Y. (2005). "Perkembangan Penelitian Pembelajaran Berbasis Inkuiri dalam Pendidikan Sains". Makalah di peresentasikan dalam Seminar Nasional II Himpunan Ikatan Sarjana dan Pemerhati Pendidikan IPA Indonesia Bekerja sama dengan FMIPA Universitas Pendididkan Indonesia.

Sanjaya, Wina. (2010). Kurikulum dan Pembelajaran Teori dan Praktik Pengembangan Kurikulum Tingkat Satuan Pendidikan (KTSP). Jakarta: Kencana Prenada Media Group

Scradamalia, Marlene. (2002). "Collective Cognitive Responsibility for the Advacement of Knowledge, In B smith (Ed)". Liberal Education. pp. 67-98.

Smasal, Randi, Molohon, Kevin, and Huynh, Richi. (2006). "Promoting Science Literacy Through Inquiry". lowa Science Teacher Journal. Vol.33, pp. 12-18.

Sproken-Smith, Rachel et al. (2007) "How Effective is Inquiry-Based Learning in Linking Teaching and Research". Paper

Marwell, Winchester, UK, ( 2007). Prepared for An International Colloquium on International Policies and Practices for Academic Enquiry.

Sugiono. (2008). Metode Penelitian Pendidikan Pendekatan Kuantitatif, Kualitatif dan R\&D. Bandung: Alfabeta

Suarsana, Made dan Wahyuni, Putu Sri. (2011). "Global Warming Ancaman Nyata Sektor Pertanian dan Upaya Mengatasi Kadar Karbondioksida Atmosfer". WIDYATECH Jurnal Sains dan Tekhnologi. Vol. 11 No 1 Agustus 2011, pp. 31-46.

Sund, Robert B. and Trowbridge, Leslie W. (1973). Teaching Science in the Secondary School. Ohio: Charles E. Merril Publishing Company.

Suyono dan Hariyanto. (2011). Belajar dan Pembelajaran. Bandung: PT. Remaja Rosdakarya

Team Sos. (2011). Pemanasan Global Solusi dan Peluang Bisnis. Jakarta: Gramedia Pustaka Utama 
Thiagarajan, S., Semmel, D. S and Semmel, M. I. (1974). Instructional Development for Training Teachers of Expectional Children. Minneapolis, Minnesota: Leadership Training Institute/Special Education, University of Minnesota..

Thomson, Sue and Bortoli, Lisa De. (2008). Exploring ScientificLiteracy: How Australia Measure Up. Camberwell, Vic: ACER.

Thomson, Sue., Hillman, Kylie., and Bortoli, Lisa De. (2013). A Teacher's Guide to PISA Scientific Literacy. Melbourne: ACER

Tim TIMSS Indonesia. (2014). Survei Internasional TIMMS

[Online]

http://litbang.kemdikbud.go.id/index.php/surveiinternasional-timss. (diakses: 20 Februari, 2014)
Toharuddin, Uus., Hendrawati, Sri dan Rustaman, Andrian. (2011). Membangun Literasi Peserta didik. Bandung: Humaniora.

Trowbridge, Leslie W. and Bybee, Rodger W. (1996). Teaching Secondary School Science-Strategies for Developing Scientific Literacy. New Jersey: Prentice Hall, 1996.

UNESCO. (2008). Sceince Eduction Policy-Making Eleven Emerging issues. s.l. : UNESCO.

Wenning, Carl J. (2011). Level of Inquiry: Hierarchies of Pedagogical Practices and Inquiry Procesess. s.l. : Illinois State University.

Zohar, A., and Aharon-Kravetsky, S. (2005). Exploring the Effects of Cognitive Conflict and Direct Teaching for Students of Different Academic Levels. Journal of Research in Science Teaching, Vol 42 No 7 2005. pp., 829-855. 